\title{
Spatial distribution and esterase activity in populations of Aedes (Stegomyia) aegypti (Linnaeus) (Diptera: Culicidae) resistant to temephos
}

\author{
Wanessa Porto Tito Gambarra ${ }^{[1]}$, Walter Fabrício Silva Martins ${ }^{[1]}$, \\ Maurício Lilioso de Lucena Filho ${ }^{[1]}$, Ingredy Meneses Cavalcanti de Albuquerque ${ }^{[1]}$, \\ Otávia Karla dos Santos Apolinário ${ }^{[2]}$ and Eduardo Barbosa Beserra ${ }^{[1]}$
}

[1]. Laboratório de Entomologia, Núcleo de Sistemática e Bioecologia de Insetos, Departamento de Biologia, Universidade Estadual da Paraíba, Campina Grande, PB. [2]. Departamento de Geografia, Universidade Estadual da Paraíba, Campina Grande, PB.

\begin{abstract}
Introduction: The need for studies that describe the resistance patterns in populations of Aedes aegypti (Linnaeus) in function of their region of origin justified this research, which aimed to characterize the resistance to temephos and to obtain information on esterase activity in populations of Aedes aegypti collected in municipalities of the State of Paraíba. Methods: Resistance to temephos was evaluated and characterized from the diagnostic dose of $0.352 \mathrm{mg}$ i.a./L and multiple concentrations that caused mortalities between $5 \%$ and $99 \%$. Electrophoresis of isoenzymes was used to verify the patterns of esterase activity among populations of the vector. Results: All populations of Aedes aegypti were resistant to temephos, presenting a resistance rate (RR) greater than 20. The greatest lethal dose $50 \%$ of the sample $\left(\mathrm{CL}_{50)}\right.$ was found for the municipality of Lagoa Seca, approximately forty-one times the value of $\mathrm{CL}_{50}$ for the Rockefeller population. The populations characterized as resistant showed two to six regions of $\alpha$ and $\beta$-esterase, called EST-1 to EST-6, while the susceptible population was only seen in one region of activity. Conclusions: Aedes aegypti is widely distributed and shows a high degree of resistance to temephos in all municipalities studied. In all cases, esterases are involved in the metabolism and, consequently, in the resistance to temephos.
\end{abstract}

Keywords: Aedes aegypti. Resistance to insecticides. Esterase.

\section{INTRODUCTION}

Studies carried out in many municipalities show that resistance of Aedes aegypti to temephos is widely spread in Brazil ${ }^{1-4}$. In Paraíba, this resistance was observed in populations from the municipalities of Boqueirão, Brejo dos Santos, Campina Grande, Itaporanga and Remígio ${ }^{3}$. Such reports confirm the need to evaluate, routinely, the efficiency of insecticides used in fighting $A$. aegypti as a security measure to public health.

Detection of this resistance and knowledge of the mechanisms involved are fundamental in order to understand the basic aspects involved in this process, and provide important information for its management in target species ${ }^{5}$. An essential aspect for the development of resistance management strategies is to determine its dynamics developing studies that evaluate the changes and frequency throughout time ${ }^{6}$.

\footnotetext{
Address to: Dra. Wanessa Porto Tito Gambarra. Av. das Baraúnas 351, Campus Universitário, Bodocongó, 58109-753 Campina Grande, PB, Brasil. Phone: 55 16 3351-8315.

e-mail: nessynhaporto@gmail.com

Received 31 July 2012

Accepted 20 February 2013
}

To achieve success in the resistance management of temephos and vector control, it is necessary to determine how the populations of the insect are distributed, once sampling and control efforts must concentrate in these places and at periods favorable to the occurrence of outbreaks of populations. Information on spatial and geographic distribution of populations of $A$. aegypti resistant to temephos guide the development and implementation of control strategies as it helps in the discovery of vulnerable points of the insect, which might be useful for guiding these actions, lowering expenses and decreasing the environmental costs due to the use of inadequate techniques.

Characterization of the esterase activity present in natural populations of $A$. aegypti is also a very useful tool for insecticide resistance management programs and vector control, since it shows the genetic variability among vector resistant populations. Detection of genetically distinct vector populations within a region may have important implications for public health, since these might be associated with behavioral, ecological and biological variations, and with epidemiologic characteristics shown by the vector.

Since the 1960s, isoenzymes have been important tools for geneticists and, although new molecular techniques have emerged, these markers are still widely used in genetic studies ${ }^{7}$. Their use is relatively inexpensive and technically accessible, which allows the analysis of several loci simultaneously ${ }^{8}$.

Isoenzymes are an efficient tool in studies of population biology and, when associated with studies of developmental 
biology and of insecticide resistance of insects, provide fundamental information in order to define control strategies for vector insects. This study aimed to characterize resistance to temephos and obtain information on esterase activity in resistant populations of $A$. aegypti collected in municipalities of the State of Paraíba, with the purpose of helping health officials develop strategies to monitor and control the populations of this vector.

\section{METHODS}

The research was conducted by studying populations of Aedes aegypti collected in six municipalities located in the mesoregion of Paraíba: Campina Grande, Esperança, Lagoa Seca, Alagoa Nova, Alagoa Grande, and Serra Redonda.

The collections were performed in neighborhoods with high rates of vector infestation according to the health department of each municipality - point $\mathrm{A}$ - and in equidistant neighborhoods, located $500 \mathrm{~m}, 1,000 \mathrm{~m}$ and $1,500 \mathrm{~m}$ from point $\mathrm{A}$. constituting points $\mathrm{B}, \mathrm{C}$ and $\mathrm{D}$, respectively.

The SB-25-Y-C-I charter, scale 1/100,000, was used as basis in order to prepare the spatial distribution maps of collection points of A. aegypti, which contained the municipalities that are part of the study area. The cartographic material is available on the website of the Executive Agency for the Management of the Waters of the State of Paraíba (EFSA) ${ }^{9}$. The coordinates of the collection points of A. aegypti were inserted on the already georeferenced map in order to show its real distribution in space and precisely indicate the location of the culicid populations resistant or non-resistant to temephos.

Thirty traps to collect eggs (ovitrap) were installed in areas defined as points A, B, C and D, distributed in houses randomly chosen in intra and peridomestic structures. The traps were collected every four days after installation and brought to the laboratory for the quantification of the number of eggs, identification of the species, and the establishment of the populations. The infestation for oviposition traps index (OTI) was calculated from the data obtained with the given formula: OTI = (no. of houses with positive traps/no. of inspected houses) X 100.

Biological testing of resistance, the establishment of the populations of $A$. aegypti and isoenzymes electrophoresis were conducted in the Laboratory of Entomology of the Nucleus of Systematics and Bioecology of Insects of the State University of Paraíba, in air conditioned rooms at a temperature of $26^{\circ} \mathrm{C} \pm$ $2^{\circ} \mathrm{C}$ and photoperiod of $12 \mathrm{~h}$. The establishment of the $A$. aegypti colonies in the laboratory followed the raising methodology described in Beserra et $\mathrm{al}^{10}$.

Technical grade temephos of first laboratory generation $\left(\mathrm{F}_{1}\right)$ and Temephos Abate ${ }^{\circledR}$ of first and second laboratory generations $\left(\mathrm{F}_{1}\right.$ e $\left.\mathrm{F}_{2}\right)$ were evaluated in the biological resistance tests.

Determination of the diagnostic dose was performed through tests of multiple concentrations that caused mortalities between $5 \%$ and $99 \%$, considering double the $\mathrm{CL}_{90}$ of the susceptible population (S) as diagnostic dose, according to what states the World Health Organization ${ }^{11}$. The Rockefeller population, kept in the Entomology laboratory for four years without selection pressure, was chosen as the susceptible population of reference $(\mathrm{S})$.

The verification and evaluation of the resistance degrees of the populations of $A$. aegypti to temephos were performed from the diagnostic dose determined from tests with the susceptible population (S), and from multiple concentrations that provide mortality between 5\% and 99\%. For each test, larvae from the late third stage $\left(\mathrm{L}_{3}\right)$ and/or from the early fourth stage $\left(\mathrm{L}_{4}\right)$ of the vector were distributed in disposable cups of $500 \mathrm{ml}$ containing $400 \mathrm{ml}$ of each solution diluted in distilled water and 25 larvae. Four replications were performed, and, after $24 \mathrm{~h}$ of exposure of larvae to the product, the mortality percentage was evaluated according to the WHO criteria for the susceptibility pattern interpretation: $\geq 98 \%$, susceptible population; $80 \%$ to $98 \%$, resistance verification; $\leq 80 \%$, resistant population.

Due to the insufficient quantity of eggs from the first laboratory generation $\left(\mathrm{F}_{1}\right)$, the resistance characterization was performed with the $\mathrm{F}_{2}$ generation of populations from Alagoa Nova D, Alagoa Grande B, Lagoa Seca C and Serra Redonda B. Only one point was chosen in each municipality in order to apply the multiple concentrations that provide mortality between $5 \%$ and $99 \%$. These populations were subjected to eight multiple concentrations of $1.76 \mathrm{mg} / \mathrm{L}$ to $8.8 \mathrm{mg} / \mathrm{L}$.

Mortality data for each population were submitted to Probit analysis using the POLO-PC program, and the resistance rate (RR) was calculated from the $\mathrm{CL}_{50}$ of the resistant population $(\mathrm{R})$ and the $\mathrm{CL}_{50}$ of the susceptible laboratory population (S). Differences between geographic populations were considered significant if $95 \%$ of the confidence intervals of $\mathrm{CL}_{50}$ did not overlap ${ }^{12}$.

Only twenty of the twenty-four samples of the collected populations of $A$. aegypti were subjected to isoenzyme electrophoresis. It was not possible to conduct these analyses for the populations of Lagoa Seca point B, Campina Grande point $\mathrm{D}$ and Esperança points $\mathrm{B}$ and D due to lack of larvae hatching.

The larvae from the first laboratory generation $\left(\mathrm{F}_{1}\right)$ of each population of $A$. aegypti $(\mathrm{n}=36)$ were homogenized in $50 \mu 1$ of extraction buffer Tris- $\mathrm{HCl} 0.5 \mathrm{M}, \mathrm{pH} 6.8$ under cooling and, subsequently, they were centrifuged at $10,000 \mathrm{rpm}$ for $10 \mathrm{~min} / 4^{\circ} \mathrm{C}$.

Afterwards, the supernatant was transferred to micro tubes of $2.0 \mathrm{ml}$ with a precision pipette and $3.0 \mu \mathrm{L}$ of bromophenol blue were added. Then, the tubes were kept in a freezer until the moment of electrophoretic analyses.

An aliquot of $15 \mu \mathrm{L}$ of protein extract was subjected to native polyacrylamide gel electrophoresis $7.5 \%$. The electrophoretic run was conducted at the amperage of $0.70 \mathrm{~A}$ and voltage of $170 \mathrm{~V} / 5 \mathrm{~h}$. Subsequently, the gel was subjected to histochemical staining specific to the Esterase alpha and beta (EST, EC 3.1.1.1) enzymatic system. The enzymatic revelation was carried out in an oven at $37^{\circ} \mathrm{C}$ for $1 \mathrm{~h}$. The fixation process was performed according to the methodology described by Alfenas et $\mathrm{al}^{13}$.

The analysis of zymograms was performed following the nomenclature described by Tabachnick and Powell ${ }^{14}$ in 1979 , where loci and alleles are designated by numbers. Allelic frequencies, heterozygosity rates and test of Hardy-Weinberg equilibrium were calculated by means of the programs TFPGA - Tools for Population Genetic Analysis ${ }^{15}$ and GenALEx $6.4^{16}$.

The construction of the dendrogram was based on the presence and absence of esterase loci through the Unweighted Pair Group Method with Arithmetic Mean (UPGMA). In this analysis, the four points of each municipality were grouped as a single one, totaling six municipalities plus the susceptible population. 


\section{RESULTS}

The maps built from this study show the real distribution in space and precisely indicate the location of the populations of
Aedes aegypti resistant to temephos (Figure 1). Therefore, they may contribute to making decisions that effectively control this vector in the region of study.

A high oviposition trap index was observed in most of the cities studied. The highest OTI was that of Serra Redonda, and

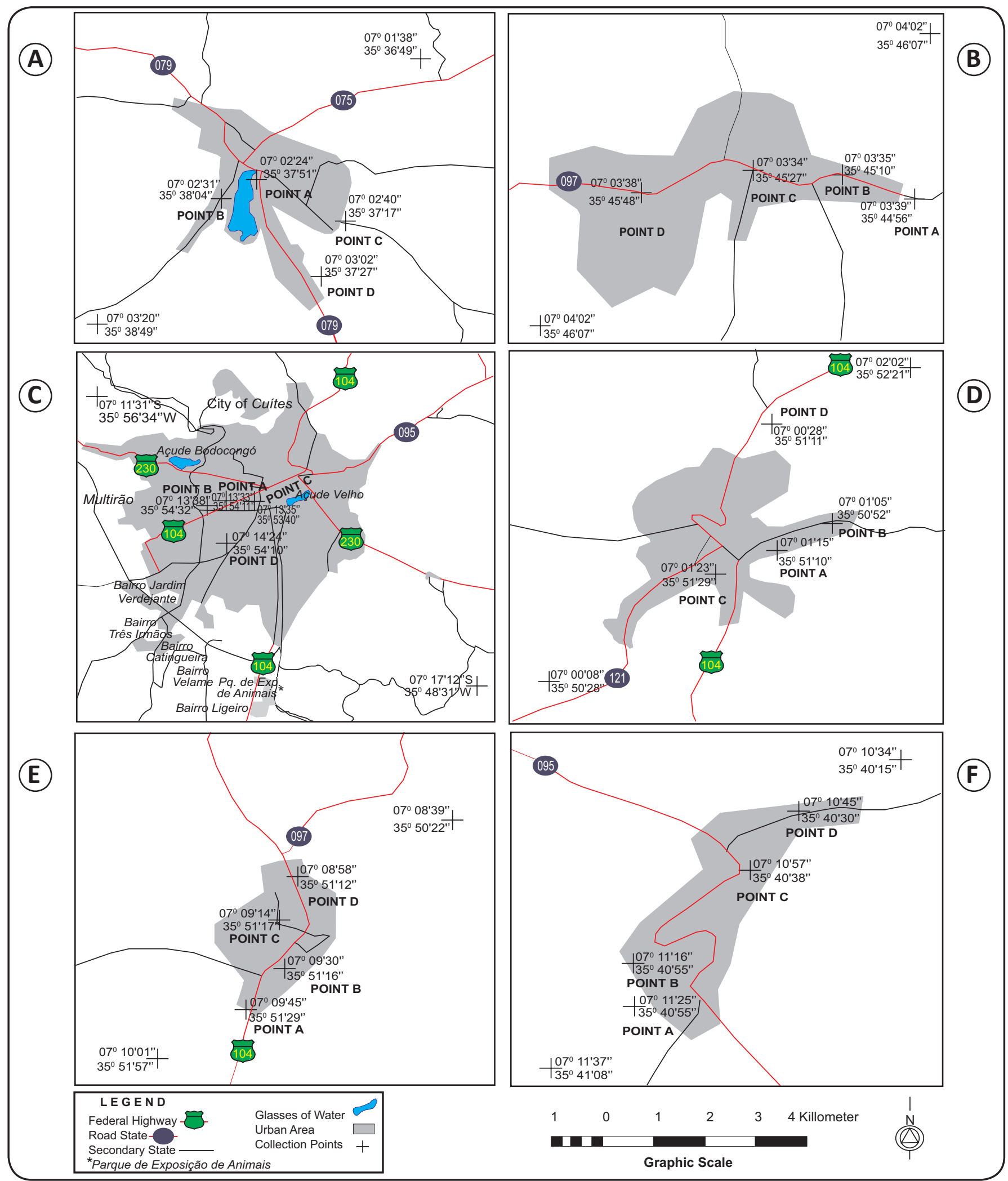

FIGURE 1 - Map of sampling sites in the State of Paraíba: A) Alagoa Grande; B) Alagoa Nova; C) Campina Grande; D) Esperança; E) Lagoa Seca; F) Serra Redonda. 


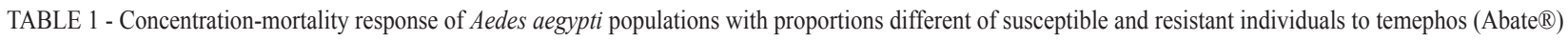

\begin{tabular}{lccccc}
\hline Populations & $\mathrm{LD}_{50}(\mathrm{CI} 95 \%)$ & $\mathrm{LD}_{90 \%}(\mathrm{CI} 95 \%)$ & $\mathrm{b}( \pm \mathrm{SE})$ & $\chi^{2}$ & $\mathrm{DF}$ \\
\hline Rockefeller & $0.107(0.090-0.121)$ & $0.201(0.184-0.225)$ & $4.692 \pm 0.581$ & 12.560 & 22 \\
Alagoa Nova & $3.813(3.545-4.096)$ & $7.577(6.760-8.802)$ & $4.297 \pm 0.311$ & 25.698 & 22 \\
Alagoa Grande & $2.668(2.501-2.826)$ & $4.248(3.921-4.738)$ & $6.345 \pm 0.548$ & 21.662 & 19 \\
Serra Redonda & $2.866(2.697-3.030)$ & $4.984(4.611-5.499)$ & $5.331 \pm 0.407$ & 7.815 & 22 \\
Lagoa Seca & $4.114(3.849-4.391)$ & $7.424(6.700-8.511)$ & $4.999 \pm 0.334$ & 40.172 & 26.1 \\
\hline
\end{tabular}

$\mathrm{LD}_{50 \%}$ : lethal dose $50 \%$ of the sample; CI: confidence interval; $\mathrm{LD}_{90 \%}$ : lethal dose $90 \%$ of the sample; b: slope; \pm SE: standard error; $\chi^{2}$ : chi-square; DF: degree of freedom; RR: resistance ratio.

the lowest OTI was that of Campina Grande. Nonetheless, it is worth highlighting that there was a significantly high rate of this index for the other municipalities, for instance, the area $\mathrm{C}$ of Esperança, whose OTI was of $90 \%$.

A number of 10,184 eggs were collected in a total of 720 ovitraps installed. The municipality with the greatest number of collected eggs was Serra Redonda, 2893; followed by Esperança, Alagoa Nova, Lagoa Seca, Lagoa Grande and Campina Grande with $2505,1658,1452,1227$ and 449 respectively.

A high degree of resistance to temephos was observed in the twenty-four populations of $A$. aegypti collected in the six municipalities from State of Paraíba. All populations had $0 \%$ mortality for the diagnostic dose of $0.092 \mathrm{mg}$ of i.a./L of technical grade and $352 \mathrm{mg}$ of i.a./L of Temephos Abate ${ }^{\circledR}$. The Rockefeller population was the only susceptible one, presenting $100 \%$ mortality, as expected.

In this study, all populations presented an increase in mortality as temephos concentration was increased (Figure 2). At concentration $8.8 \mathrm{mg} / \mathrm{L}$ of this larvicide, mortality reached $100 \%$ in four of the municipalities tested. Mortality observed for the Rockefeller strain was of $100 \%$ for all dosages tested, validating the results for the other populations.

The $\mathrm{CL}_{50 \mathrm{~s}}$ for the populations studied were higher than the $\mathrm{CL}_{50}$ for Rockefeller, and the municipalities of Lagoa Seca and Alagoa Nova presented the highest values; 4.114 and 3.813. The highest $\mathrm{CL}_{90}$ (7.577) was obtained for Alagoa Nova, approximately thirty-eight times the value of $\mathrm{CL}_{90}(0.201)$ for the susceptible population (Table 1).

All populations studied presented mortality rates lower than $80 \%$, therefore, they were considered resistant and the resistance rate was higher than 20 .

The increase in esterase gene expression was confirmed by the tests carried out in twenty populations from the mesoregion of rural Paraíba, allowing the visualization of six regions of $\alpha$ and $\beta$-esterase in resistant populations called EST-1 to EST-6. Only the Rockefeller population presented a low esterase activity, which was expected, since it is a susceptible population.

Two loci presented only one allele (EST-3, EST-6), three loci presented two alleles (EST-1, EST-4, EST-5) and only one locus presented three alleles (EST-2), with a predominance of three loci in $38 \%$ of the populations with strong, medium and weak intensity observed in various regions of the gel.

Populations characterized as resistant showed from two to six regions of esterase activity, while only one region of activity

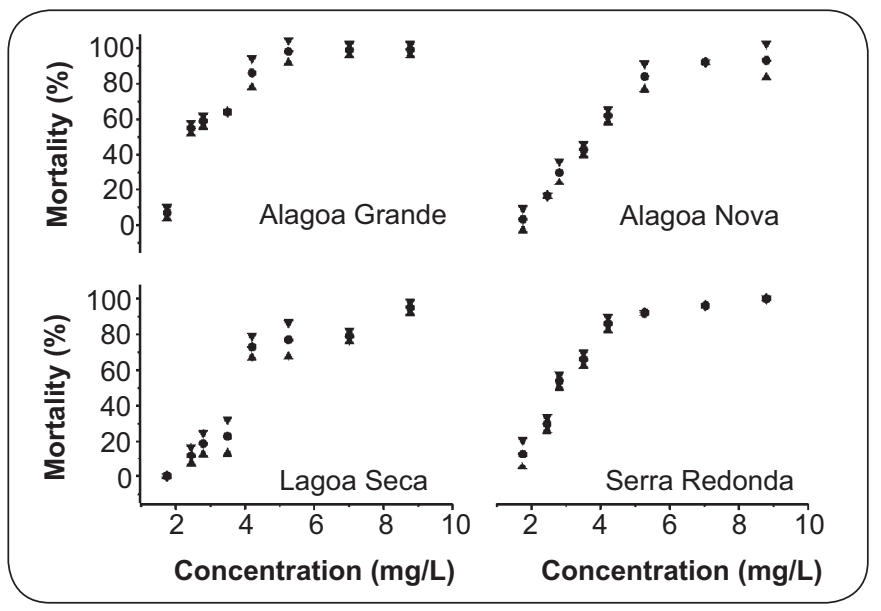

FIGURE 2 - Temephos Abate ${ }^{\circledR}$ toxicity in four Aedes aegypti populations.

was observed for the susceptible population (Rockefeller). The confirmation that these patterns differentiate resistant and susceptible insects was obtained by the resistance verification test, once all larvae tested survived the diagnostic dose of $0.352 \mathrm{mgi} . \mathrm{a} . / \mathrm{L}$, which was lethal for the Rockefeller population.

The pattern of the six loci evaluated showed the presence of 13 alleles (Est-1 ${ }^{1}$, Est-2 ${ }^{1}$, Est-2 ${ }^{2}$, Est-2 ${ }^{3}$, Est-3 ${ }^{1}$, Est- $3^{2}$, Est-4 ${ }^{1}$, Est- $4^{2}$, Est- ${ }^{1}$, Est- ${ }^{2}$, Est- $5^{3}$, Est- $6^{1}$ and Est- $6^{2}$ ), and allele Est- $2^{2}$ was the only one present in all populations analyzed with allelic frequencies ranging between 0.083 and 1 .

The samples of $A$. aegypti from point $\mathrm{D}$ of the municipalities of Serra Redonda and Alagoa Grande correspond to the areas with the highest proportion of polymorphic loci, $66.6 \%$ and $50 \%$, respectively, which shows a greater genetic variability in these populations.

The average heterozygosity was higher in point A of Serra Redonda and Campina Grande, 0.3369 . The patterns of esterase loci detected for the populations of Alagoa Grande point C, Alagoa Nova points A and B, Lagoa Seca point A and Rock revealed monomorphism in all loci. Most of the populations studied presented $16.6 \%$ of polymorphic loci.

The populations with greater esterase activity presented lower resistance to temephos, such as Serra Redonda and Alagoa Grande. These cities probably suffer less insecticide selection pressures. It can be seen that the higher the number of loci the greater the resistance, expect for Lagoa Seca (Table 2). 
TABLE 2 - Number of loci and the ratio of the resistance of Aedes aegypti populations that were tested for resistance characterization

\begin{tabular}{lcc}
\hline Populations & Number of loci & RR \\
\hline Lagoa Seca Point C & 3 & 41.1 \\
Alagoa Nova Point D & 5 & 38.1 \\
Serra Redonda Point B & 4 & 28.6 \\
Alagoa Grande Point B & 4 & 26.6 \\
\hline
\end{tabular}

RR: resistance ratio.

A binary matrix for the presence or absence of loci was generated from the data. From this matrix, it was possible to build a dendrogram (Figure 3) to estimate the divergence for the populations studied.

Five distinct groups can be observed in the dendrogram. The populations of Alagoa Grande and Lagoa Seca are the only ones that have a collection point in which all loci are monomorphic. The percentage of polymorphic loci was also similar, $20 \%$ and $16 \%$, respectively.

The population from Serra Redonda was isolated once it presented the greatest quantity of polymorphic loci, $41 \%$. Its proximity to the groups from populations 1 and 5 is due to the fact that the populations of Serra Redonda and Alagoa Grande are the only ones that have six loci in one collection point: Est-1, Est-2, Est-3, Est-4, Est-5, Est-6.

Alagoa Nova formed a third group and is the only one that has two polymorphic loci. The populations of Campina Grande and Esperança, respectively, are similar due to the presence of the same sequence of the loci Est-2, Est-4 and Est-5. Esperança point $\mathrm{C}$ does not have this last locus. The Rockefeller population formed the last group and is the only susceptible population having just one monomorphic locus.

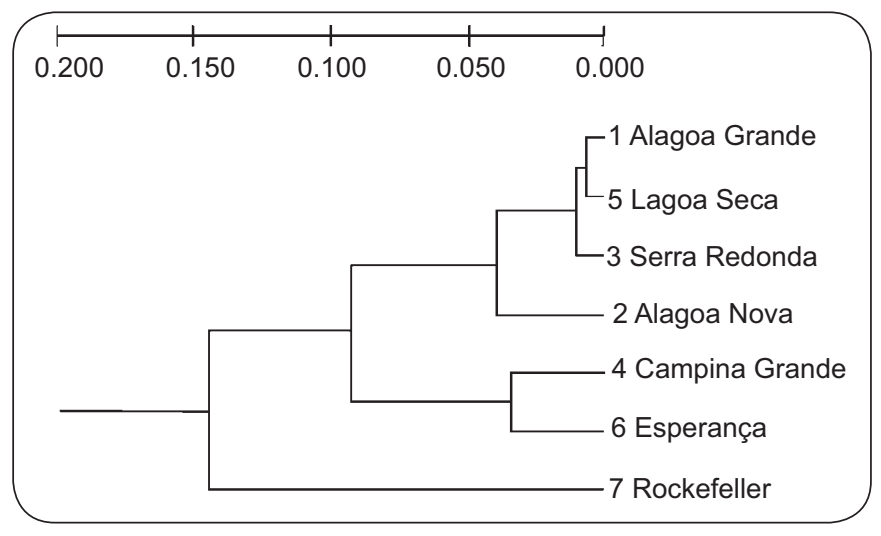

FIGURE 3 - Dendrogram showing cluster analysis among Aedes aegypti populations from State of Paraíba, based on the presence and absence of esterase loci, the Unweighted Pair Group Method with Arithmetic Mean (UPGMA).

\section{DISCUSSION}

Distribution of Aedes aegypti is increasingly wider. The high oviposition trap index found for the cities studied may be explained due to the fact that collections were performed in the summer. This can be easily understood once high temperatures influence culicid larvae hatching.

It was also observed that the water supply was irregular and via water tanker trucks in some cities with the need to store water in tanks, containers and others, all without cover, which favored the development of the mosquito ${ }^{17}$.

The number of Brazilian municipalities where the presence of $A$. aegypti has been verified has rapidly increased over the past years. In a study performed in Ilha do Governador in Rio de Janeiro, Souza-Santos and Carvalho ${ }^{18}$ observed that the presence of the mosquito was greater in residential areas; however, it is not restricted to those areas, since the mosquito is distributed throughout the region.

The use of ovitraps was shown to be a good tool to study vector infestation. Braga et $\mathrm{al}^{19}$. indicated the monitoring with ovitraps as a more sensitive and economical methodology when compared to official monitoring methodologies based on larval research. That is in agreement with Marques et $\mathrm{al}^{20}$. who found on the ovitrap the capacity for positive findings even in the presence of a great number of competing breeding places. One of the advantages of using ovitraps would be the withdrawal of eggs from the environment ${ }^{21}$.

In the State of Paraíba, Beserra et al. observed the resistance of $A$. aegypti populations from Boqueirão and Remígio using a concentration of $0.012 \mathrm{mg}$ i.a. $/ \mathrm{L}$ of technical temephos. These cities presented mortalities of $4.8 \%$ and $48 \%$, respectively. The populations of Brejo dos Santos, Campina Grande, Itaporanga, Capim de Cheiro and Lagoa do Mato presented mortality below $80 \%$ for all tests.

The high resistance rate (RR) found in this study is worrying, since, according to Mazzari and Georghiou ${ }^{22}$, RR above 10 is considered a compromising level for the larvicide action, causing damage to programs of vector control. For larvae that presented RR of this magnitude, the residual effect to temephos in the field will be lower, since there is gradual decline in the concentration available initially in the treated deposits, which contributes to the increase in the number of surviving larvae along time. This causes the need for a greater number of larvicide applications in shorter intervals, with the consequent increase in costs of dengue combating programs ${ }^{2}$.

The high resistance pattern observed for the populations investigated may be associated with the use history of the product in each locality with different intensities or application frequencies, subjecting them to different selection pressures with consequent increase in resistance for some, or, probably, to resistance mechanisms developed in each population.

The increase in esterase activity seen in this study was also shown in resistant populations of Myzus persicae, in some Culex and Nilaparvata lugens mosquitoes ${ }^{23,24}$. Maymo'o et al ${ }^{25,26}$. also observed the increase in esterase genes activity when studying populations of Frankliniella occidentalis from southwestern Spain.

In the search for esterases that are connected to the resistance condition or susceptibility of the analyzed populations, some esterases and some esterase combinations could be involved in one of the resistance mechanisms, and should be submitted 
to a more thorough study; they are: the EST-2 locus, alone, for its presence in all resistant populations, or along with EST-4, occurring in 17 of the 21 evaluated populations.

Esterase patterns have already been successfully used in genetic differentiation of populations of insects resistant to chemical insecticides ${ }^{20,27-30}$. It has been possible to reveal esterase patterns capable of differentiating resistant and susceptible populations for A. aegypti populations from São Paulo and Bahia ${ }^{29}$.

Paiva $^{31}$ verified, through electrophoresis, a total of five regions of $\alpha$ and $\beta$-esterase for the resistant populations when studying A. aegypti populations from nine localities in the State of Pernambuco. Only one activity region was seen for the Rockefeller population.

Yan et $\mathrm{al}^{32}$. found an average heterozygosity of $0.604 \mathrm{using}$ RFLP markers in $A$. aegypti populations exposed to DDT; this value is well above those found in this research, 0.3369 . Nevertheless, this increase was already expected once the RFLP marker analyzes the whole genome.

The high resistance presented by the population of Lagoa Seca, even though it has only three loci (Table 2), can be explained since the analysis of the isoenzyme gels revealed the expression of the Est- $4^{2}$ allele, only present in this population, which might have afforded a higher enzymatic activity in this locus. The identification of an allele responsible for the resistance was also reported by Rodriguez et $\mathrm{al}^{33}$. in samples of $A$. aegypti resistant to temephos.

López-Soler et $\mathrm{al}^{34}$. reported the presence of a characteristic pattern of bands that showed a strong correlation between total esterase activity and resistance degree in their studies on the evaluation of esterase gene in the resistance of Frankliniella occidentalis through polyacrylamide gel electrophoresis.

It can be verified that $A$. aegypti is widely distributed and has high infestation indices (OTIs) in the six municipalities of Paraíba, besides presenting high resistance degrees to temephos $(R R>20)$. It was also seen that esterases may be involved in the vector resistance to temephos in all samples of the populations evaluated and that the greater the quantity of loci, the higher the resistance, once the greater the quantity of esterases, the greater the chances the mosquito would metabolize temephos. However, there is no evidence that only the esterases are indeed the cause of this high resistance, other mechanisms may also be involved.

Such data show the continuing need for monitoring the resistant to insecticides used in fighting $A$. aegypti as a security measure to public health.

These results need further corroboration, in addition to a more detailed study on the esterase gene. The next challenge consists in incorporating genetic data into control programs as a tool to evaluate the effectiveness of the actions to control $A$. aegypti.

\section{ACKNOWLEDGMENTS}

The authors wish to thank the Municipal Health Departments of Campina Grande, Esperança, Lagoa Seca, Alagoa Nova, Alagoa Grande and Serra Redonda for the information provided and the support given to this project.

\section{CONFLICT OF INTEREST}

The authors declare that there is no conflict of interest.

\section{FINANCIAL SUPPORT}

Programa de Incentivo à Pós-Graduação e Pesquisa (PROPESQ) of Universidade Estadual da Paraíba (UEPB).

\section{REFERENCES}

1. Marcoris MLG, Andrighetti MTM, Takaku L. Resistance of Aedes aegypti from the State of São Paulo, Brazil, to organophosphates insecticides. Mem Inst Oswaldo Cruz 2003; 98:703-708.

2. Lima EP, Oliveira Filho AM, Lima JWO, Ramos Júnior AN, Cavalcanti LPG, Pontes RJS. Resistência do Aedes aegypti ao Temefós em Municípios do Estado do Ceará. Rev Soc Bras Med Trop 2006; 39:259-263.

3. Beserra EB, Fernandes CRM, Queiroga MFC, Castro-Jr FP. Resistência de Aedes aegypti (L.) (Diptera: Culicidae) ao organofosforado temefós na Paraíba. Neotrop Entomol 2007; 36:303-307.

4. Prophiro JS, Silva OS, Luna JED, Piccoli CF, Kanis LA, Silva MAN. Aedes aegypti and Aedes albopictus (Diptera: Culicidae): coexistence and susceptibility to temephos, in municipalities with occurrence of dengue and differentiated characteristics of urbanization. Rev Soc Bras Med Trop 2011; 44:300-305.

5. Cruz P. Manejo da Resistência de Insetos-Praga a Inseticidas, com ênfase em Spodoptera frugiperdra (Smith). Embrapa Milho e Sorgro; 2002. [Cited 2009 April]. Available from: http://www.cnpt.embrapa.br/.

6. Campos JF, Omoto C. Estabilidade da resistência de Brevipalpus phoenicis (Geijskes) (Acari: Tenuipalpidae) a Hexythiazox em Pomares de citros. Neotrop Entomol 2006; 35:840- 848.

7. Souza-Santos R, Carvalho MS. Análise da distribuição espacial de larvas de Aedes aegypti na Ilha do Governador, Rio e Janeiro, Brasil. Cad Saue Publica 2000; 16:31-42.

8. Augustin E, Loeck AE, Storch G, Grutzmacher DD, Afonso APS, Gusmão LG. Identificação de formigas cortadeiras do gênero Acromyrmex (Hymenoptera: Formicidae) através de isoenzimas. Rev Bras de Agrociência 1999; 5:217-220.

9. Agência Executiva de Gestão das Águas do Estado da Paraíba (AESA) [Website]. Available from: http:/www.aesa.pb.gov.br/geoprocessamento/geoportal/ cad.html

10. Beserra EB, Fernandes CRM, Ribeiro PS. Relação entre densidade larval e ciclo de vida, tamanho e fecundidade de Aedes (Stegomyia) aegypti (L.) (Diptera: Culicidae) em laboratório. Neotrop Entomol 2009; 38:847-852.

11. World Health Organization (WHO). Guidelines for laboratory and field testing of mosquito larvicides: Communicable disease control, prevention and eradication. Who pesticide evaluation scheme. Geneva: WHO; 2005.

12. Sosa-Gomez DR, Corso IC, Morales L. Insecticide resistance to endosulfan, monocro to phos and metamidophos in the Neotropical brownstink bug, Euchistusheros (F.) Neotrop Entomol 2001; 30:317-320.

13. Alfenas AC, Peters I, Brune W, Passador GC. Eletroforese de proteínas e isoenzimas de fungos e essências florestais. Viçosa: Imprensa Universitária; 1991.

14. Tabachnick WJ, Powell JR. A world-wide survey of genetic variation in the yellow fever mosquito, Aedes aegypti. Genetic Researcher 1979; 34:215-229.

15. Miller MP. TFPGA: Tools for populations genetic analyses. Version 1.3. Utah State University; 1997. Computer software distributed by authors.

16. Peakall R, Smouse PE. GenAlex 6: Genetic Analysis in Excel. Camberra: The Australian National University; 2005.

17. Soares-da-Silva J, Ibiapina SS, Bezerra JMT, Tadei WP, Pinheiro VCS. Variação da infestação de Aedes aegypti (Linnaeus), (Diptera, Culicidae) em recipientes artificiais em Caxias, estado do Maranhão, Brasil. Rev Soc Bras Med Trop 2012; 45:174-179. 
18. Souza-Santos R, Carvalho MS. Análise da distribuição espacial de larvas de Aedes aegypti na Ilha do Governador, Rio e Janeiro, Brasil. Cad Saude Publica $2000 ; 16: 31-42$.

19. Braga IA, Gomes AC, Nelson M, Mello RCG, Bergamaschi DP, Souza JMP. Comparativ estudy between larval survey sand ovitraps to monitor populations of Aedes aegypti. Rev Soc Bras Med Tropical 2000; 33:347-353.

20. Marques CC, Marques GR, Brito M, Santos Neto LG, Ishibashi VC, Gomes FA. Comparative study of the efficiency of larval and ovitraps for the surveillance of dengue and yellow fever vectors. Rev de Saude Publica 1993; 27:237-241.

21. Santos A, Marçal Junior O. Geografia do Dengue em Uberlândia (MG) na Epidemia de 1991. Caminhos de Geografia 2004; 3:35-52.

22. Mazzari MB, Georghiou GP. Characterization of resistence to organophosphate, carbamate, and pyrethroid insecticides in field population of Aedes aegypti fron Venezuela. Jornal American Mosquito Control Association 1995; 11:315-322.

23. Vaughan A, Hemingway J. Mosquito carboxylesterase Est $\alpha 21$ (A2). Cloning and sequence of the full-length cDNA for a major insecticide resistance gene worldwide in the mosquito Culex quinquefasciatus. J Biol Chem 1995; 270:17044-17049.

24. Small GJ, Hemingway J. Molecular characterization of the amplified carboxylesterase gene associated with organophosphorus insecticide resistance in the brown planthopper, Nilaparvata lugens. Insect Mol Biol 2000; 9:647-653.

25. Maymó AC, Cervera A, Sarabia R, Martínez-Pardo R, Garcerá MD. Evaluation of metabolic detoxifying enzyme activities and insecticide resistance in Frankliniella occidentalis. Pest Manag Sci 2002; 58:928-934.

26. Maymó AC, Cervera A, Dolores Garcerá M, Bielza P, Martínez-Pardo R. Relationship between esterase activity and acrinathrin and methiocarb resistance in field populations of western flower thrips, Frankliniella occidentalis. Pest Manag Sci 2006; 62:1129-1137.
27. Vaugh A, Ffrench-Constant RH. Biochemical monitoring of organophosphorous and carbamate inseticide resistance in Aedes aegypti mosquitoes from Trinidad. Med Vet Entomol 1998; 12:318-332.

28. Flores AE, Albeldaño-Vázquez W, Salas IF, Badii MH, Becerra HL, Garcia GP, et al. Elevated $\alpha$-esterase levels associated with permethrin tolerance in Aedes aegypti (L.) from Baja California, Mexico. Pest. Biochem. Physiol 2005, 82:66-78.

29. Guirado MM, Bicudo HEMC. Padrão de esterases em populações do mosquito Aedes aegypti (Diptera, Culicidae), resistentes e suscetíveis a inseticidas utilizados no controle. Pôster apresentado: $54^{\circ}$ Congresso Brasileiro de Genética; 2008. Salvador, BA, Brasil.

30. Montella IR, Schama R, Valle D. The classification of esterases: an important gene family involved in insecticide resistance - A Review. Mem Inst Oswaldo Cruz 2012; 107:437-449.

31. Paiva MHS. Monitoramento do gene, que codifica a esterase, envolvido na resistência a inseticidas organofosforados em populações naturais de Aedes aegypti do Brasil. [Masters Dissertation]. [Recife]: Fundação Oswaldo Cruz/ Centro de Pesquisa Aggeu Magalhães; 2006. 89 p.

32. Yan G, Chadee DD, Severson DW. Evidence for genetic hitchhiking effect associated with insecticide resistance in Aedes aegypti. Genetics 1998; 148:793-800.

33. Rodríguez MM, Bisset J, Ruiz M, Soca A. Cross-resistance to pyrethroid and organophosphorus insecticides induced by selection with temephos in Aedes aegypti (Diptera: Culicidae) from Cuba. J Med Entomol 2002; 36:882-888.

34. López-Soler N, Cervera A, Moores GD, Martínez-Pardo R, Garcerá MD. Esterase isoenzymes and insecticide resistance in Frankliniella occidentalis populations from the south-east region of Spain. Pest Manag Sci 2008; 64:1258-1266. 